\title{
ECTOPIC PANCREATIC, GASTRIC, AND SMALL INTESTINE TISSUE IN AN UMBILICAL POLYP, CAUSING PERSISTENT UMBILICAL DISCHARGE IN A 2 YEAR OLD CHILD - A RARE CASE REPORT
}

Sangeeta Sharma, Ujwala Maheshwari, Nidhi Bansal

1. Assistant Professor, Department of Pathology, MGM Medical College. Navi Mumbai.

2. Professor, Department of Pathology, MGM Medical College. Navi Mumbai.

3. Resident, Department of Pathology, MGM Medical College. Navi Mumbai.

\section{CORRESPONDING AUTHOR}

Dr. Sangeeta Sharma, 1801, Kasturi Heights, Sector-20, Plot 39, Kharghar, Navi Mumbai, Maharashtra, India E-mail: drsangeetasharma@gmail.com Ph: $00910323009867,00918692999076$.

ABSTRACT: Umbilical polyps, containing vestigial remnants of the omphalomesentric duct, are a rare cause of persistent umbilical discharge in the paediatric age group, as compared to omphalitis or umbilical granulomas. However, umbilical polyps need to be investigated thoroughly to ensure complete resection and to rule out extension into the abdominal cavity. Further, such umbilical polyps may cause complications due to the presence of ectopic tissues inside them. The present case is the first reported case of three tissue types, viz. Pancreatic, Gastric, and Small Intestinal tissues, being present ectopically in an umbilical polyp, which had caused persistent umbilical discharge with severe local excoriation and ulceration in a 2 year old child. CONCLUSION Umbilical polyps with ectopic tissues can lead to severe complications if not treated properly, and should be ruled out in all cases of persistent umbilical discharge in the paediatric age group.

KEYWORDS - umbilical discharge; umbilical polyp; granuloma; omphalitis; ectopic tissue; ectopic pancreatic tissue; ectopic gastric tissue

INTRODUCTION: Omphalitis and umbilical granulomas are a common cause of persistent umbilical discharge in an infant. They can vary from benign lesions to severe congenital anomalies [1]. Umbilical polyps, with vestigial remnants of omphalomesentric duct and allantoic duct, are an infrequent cause of umbilical discharge. Rarely, well developed ectopic tissue may be present within these polyps. The present case is, to the best of our knowledge, the first report of ectopic Pancreatic tissue, Small Intestinal tissue, and Gastric tissue being present together in an umbilical polyp, in a 2 year old child.

CASE REPORT: A 2 year old male child presented to the Paediatric surgery OPD of our hospital with complaint of persistent discharge from the umbilicus since birth. The child was born through normal vaginal delivery following an uneventful gestational period and had no congenital anomalies. Physical examination showed a pea sized, reddish nodule in the umbilical area with severe excoriation and ulceration of the surrounding skin due to the serous discharge. No abdominal wall defects were observed. USG abdomen was normal, and revealed no intraabdominal growth from the umbilicus. The child underwent surgical umbilical exploration and a 
firm, $1.2 \mathrm{~cm} \times 1.2 \mathrm{~cm} \times 1.0 \mathrm{~cm}$, reddish nodule was found at the bottom of the umbilicus. No Meckel's diverticulum, proximal omphalomesentric duct remnants or patent urachus were found. Histology of the nodule demonstrated Pancreatic tissue along with Small Intestinal mucosa[Fig 1] and Gastric mucosa [Fig 2]. Complete resection of the nodule was confirmed. No neoplastic changes were detected. Both exocrine and endocrine Pancreatic tissue was observed, including Acini, Ducts, and Islets of Langerhans. A diagnosis of umbilical polyp with ectopic Pancreatic, Small Intestinal, and Gastric tissue was established. The patient recovered completely after the surgery.

DISCUSSION: Persistent umbilical discharge in infants and young children is a common paediatric problem, and the most common causes are omphalitis and umbilical granulomas. These are usually observed as firm, reddish nodules, found in the depth of the umbilicus. Umbilical polyps, with vestigial remnants of the omphalomesentric duct, are infrequently observed in cases of persistent umbilical discharge. These polyps usually contain ectopic Small Intestinal mucosa, but other ectopic tissues e.g. Gastric mucosa and Pancreatic tissue are rarely seen.

Ectopic gastric mucosa can be found anywhere in the Gastrointestinal (GI) tract including Meckel's diverticulum, the Gall bladder, Cystic duct, the omphalomesentric duct and the liver [3]. The overall incidence of ectopic Gastric mucosa in the GI Tract ranges from $8 \%$ to $55 \%[4,5,6]$. However, occurrence in the umbilical region is extremely rare, and we found only 2 such cases after extensive literature search. The overall incidence of ectopic Pancreatic tissue has been estimated to be 0.5 to $13 \%$ during routine pathological autopsies.[7]. Ectopic Pancreatic tissue is found at different sites in the GI tract and is most often discovered in fifth and sixth decades of life $[8,9]$. It has been reported infrequently in the paediatric age group and even more rarely near the umbilicus $[10,11]$.

The following theory has been postulated for ectopic tissues in umbilical polyps. During embryogenesis, the mid-gut rotates 90 degrees counter-clockwise within the umbilical cord, around the axis of the superior mesenteric artery, elongating to form the jejunum and ileum. By the 10th week of embryogenesis, the lumen of the omphalomesentric duct closes, and the midgut returns to the abdominal cavity [12]. The Intestinal and Gastric mucosa cells could be implanted at this point of time in the umbilical area giving rise to ectopic Small Intestinal and Gastric tissues The theories for the ectopic Pancreas are based on the foetal migration of the Pancreatic cells and the Metaplastic theory[13].

In cases of umbilical polyps, remnants of the omphalomesentric duct can extend into the stalk and also into the abdominal cavity. Therefore, complete resection needs to be confirmed by histological examination of the resected polyp, and also by imaging studies of the abdomen to rule out intra-abdominal extension.

The present case was a rare case of an umbilical polyp which contained all three ectopic tissues viz Gastric, Small Intestinal tissue and Pancreatic tissue. The Pancreatic tissue included both exocrine as well as endocrine components. Exocrine secretions of the Pancreas include proteolytic enzymes capable of extensive damage if released outside the GI tract. Therefore, umbilical polyps with pancreatic tissue can cause severe local excoriation and ulceration of the skin, leading to secondary infections and omphalitis, as was observed in the present case. Further, the ectopic tissues are prone to the same lesions as the original organs, including neoplastic change, which needs to be ruled out. 
CONCLUSION: Umbilical polyps with ectopic pancreatic tissue, even though rare, should be considered in the differential diagnosis of persistent umbilical discharge with severe local excoriation or ulceration. Complete resection of such polyps needs to be confirmed by both histological and imaging studies.

CONFLICT OF INTEREST - The authors have no potential conflict of interest

ACKNOWLEDGEMENTS - We thank the Paediatric Surgery Department of MGM Medical College and Hospital, for their valuable knowledge and discussions pertaining to the case.

\section{REFERENCES:}

1. O'Donnell KA, Glick PL, Caty MG. Pediatric umbilical problems. Pediatr Clin North Am 1998; 45:791-800.

2. W. D.D. De Silva, M.C. Samarasinghe, M.N.J.R.Dias \& C.S. Perera. Annals of Tropical Paediatrics 2010; 30:73-75.

3. Willis RA. Some unusual developmental heterotopias. Br Med J. 1968; 3:267-272.

4. Heatley MK, Mirakhur M. Cutaneous remnants of the vitellointestinal duct: a clinicopathological study of 19 cases. Ulster Med J 1988; 57:181-3.

5. Pacilli M, Sebire NJ, Maritsi D, et al. Umbilical polyp in infants and children. Eur J Pediatr Surg 2007; 17:397-9.

6. Steck WD, Helwig EB. Cutaneous remnants of the omphalomesenteric duct. Arch Dermatol 1964; 90:463-70.

7. Dolan RV, Remine WH, Dockerty MB. The fate of heterotopic pancreatic tissue - a study of 212 cases. Arch Surg 1974; 109:762-5

8. Agale VG, Zode RR, Grover S, Joshi S. Heterotopic pancreas involving stomach and duodenum. J Assoc Physicians India 2009; 57:653-7.

9. Yuan Z, Chen J, Zheng Q, Huang XY, Yang Z, Tang J.Heterotopic pancreas in the gastrointestinal tract. World J Gastroenterol 2009; 15:3701-3

10. De' Angelis GL, Del Rossi C, Romanini E, Dodi I, Ghinelli C. The aberrant pancreas in the pediatric age group: case report and review of the literature. Pediatr Surg Int 1992; 2:214-5.

11. .11 Ogata H, Oshio T, Ishibashi H, Takano S, Yagi M. Heterotopic pancreas in children: review of the literature and report of 12 cases. Pediatr Surg Int 2008; 24:271

12. Bauer SB, Retik AB. Urachal anomalies and related umbilical disorders. Urol Clin North Am. 1978; 5:195-211.

13. Sadeghi NR, Godambe A, Shienbaum AJ, Alloy A. Premalignant gastric heterotopic pancreas. Gastroenterol Hepatol 2008; 4:218-21. 


\section{CASE REPORT}

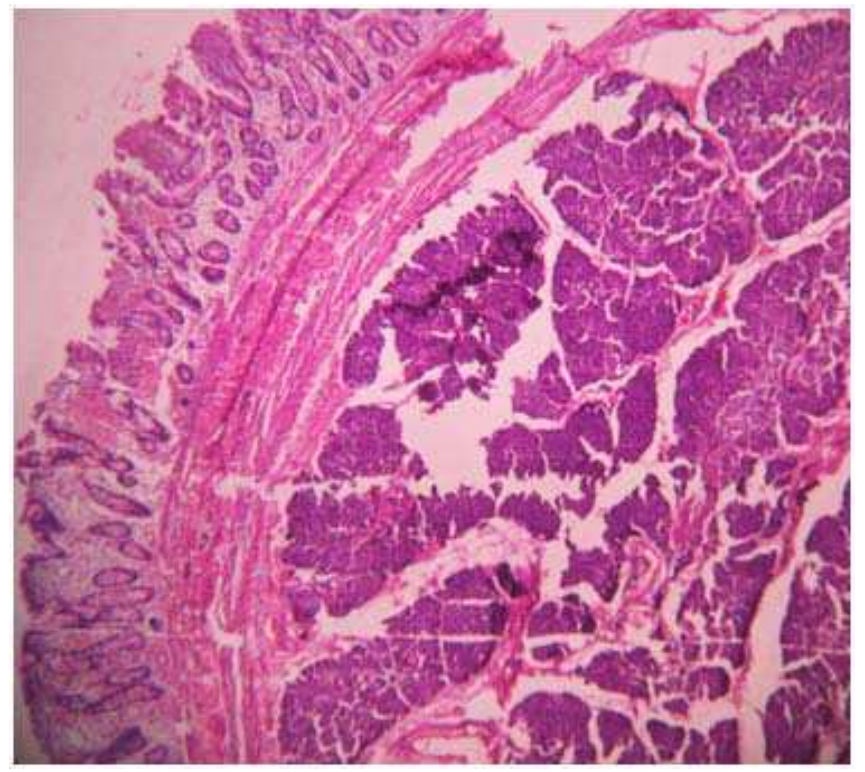

Fig-1 Ectopic Pancreas \& Small intestinal tissue( Haematoxylin \&Eosin stain 20x)

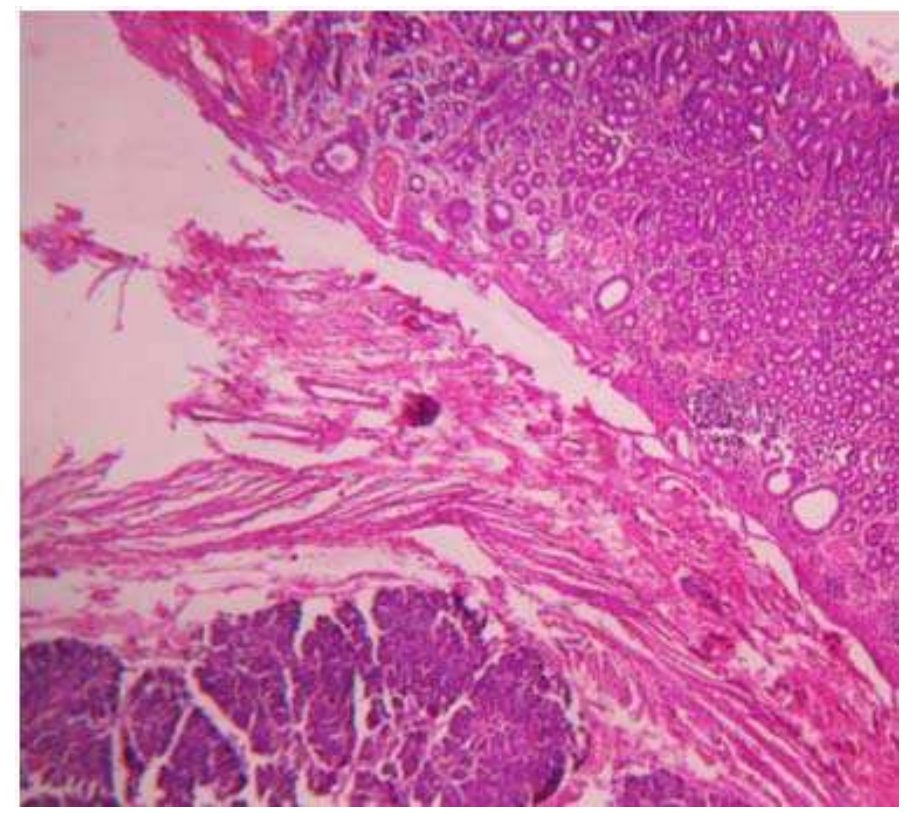

Fig-2 Ectopic Pancreas and Gastric tissue ( Haematoxylin \&Eosin stain 20x) 


\section{CASE REPORT}

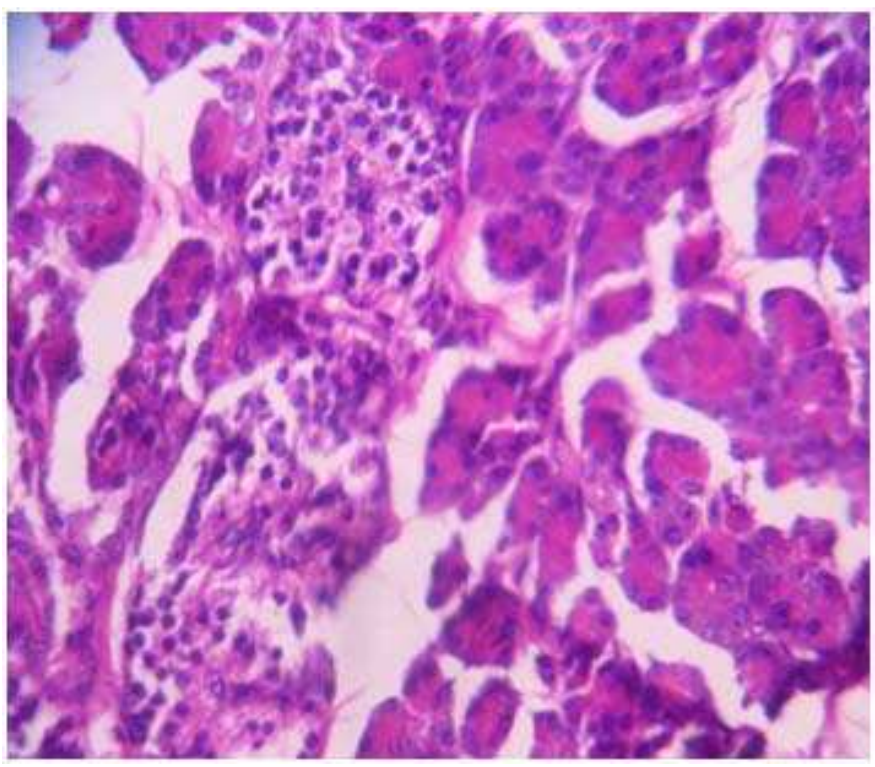

Fig 3 -Exocrine and endocrine glands of ectopic Pancreatic tissue ( Haematoxylin \&eosin stain $40 \mathrm{x}$ ) 